\title{
PENGEMBANGAN KAMUS ARAB-INDONESIA SEBAGAI PENUNJANG PENGGUNAAN BUKU AJAR MADRASAH TSANAWIYAH DI KELAS VIII
}

\author{
Nurul Huda \\ Uiniversitas Islam Negeri Sunan Kalijaga \\ Nurul.huda@uin-suka.ac.id \\ Nabilah Ulfah \\ Uiniversitas Islam Negeri Sunan Kalijaga \\ Nabilahulfah8@gmail.com
}

\begin{abstract}
Abstrac: This study aims to produce a product in the form of an Arabic-Indonesian dictionary for 8th grade MTs to support the use of textbooks. Equipped with fi'il madhi, fi'il mudhari ', and mashdar information for verbs in the form of verbs and for nouns equipped with singular and plural forms. The research model used is the Research and Development model. Methods of data collection in the form of non-tests using research instruments in the form of validation sheets, assessment sheets, and teacher and student response sheets on small scale trials and large scale trials. The results of this study are (1) have successfully developed Arabic-Indonesian dictionary products for grade 8 MTs, (2) based on the assessment of experts consisting of material experts, media experts and Arabic language teachers, this dictionary has very good quality (SB) , (3) based on a small-scale trial the students 'response to the product being developed was agreed (S) and on the large-scale trial the students' response to the Arabic-Indonesian dictionary for grade 8 MTs was strongly agreed (SS).
\end{abstract}

Keywords: Textbooks, Arabic-Indonesian Dictionary, Development

Abstrak: Penelitian ini bertujuan untuk menghasilkan sebuah produk berupa kamus Arab-Indonesia untuk MTs kelas 8 sebagai penunjang penggunaan buku ajar. Dilengkapi dengan informasi fi'il madhi, fi'il mudhari', dan mashdar untuk kata yang berbentuk kata kerja dan untuk kata benda dilengkapi dengan bentuk tunggal dan pluralnya. Model penelitian yang digunakan yakni model Research and Development. Metode pengumpulan data berupa non tes dengan menggunakan instrumen penelitian berupa lembar validasi, lembar penilaian, dan lembar respon guru dan siswa pada uji coba skala kecil dan uji coba skala besar. Hasil dari penelitian ini adalah (1) telah berhasil mengembangkan produk kamus Arab-Indonesia untuk MTs kelas 8, (2) berdasarkan penilaian para ahli yang terdiri dari ahli materi, ahli media dan guru bahasa arab, kamus ini memiliki kualitas sangat baik (SB), (3) berdasarkan ujicoba skala kecil respon peserta didik terhadap produk yang dikembangkan adalah setuju (S) dan pada uji coba skala besar respon peserta didik terhadap kamus ArabIndonesia untuk MTs kelas 8 ini adalah sangat setuju (SS).

Kata Kunci: Buku Ajar, Kamus Arab-Indonesia, Pengembangan 


\section{PENDAHULUAN}

Saat ini pelajaran bahasa Arab menjadi salah satu mata pelajaran yang wajib dipelajari di MI (Madrasah Ibtidaiyah), MTs (Madrasah Tsanawiyah), dan MA (Madrasah Aliyah). Tidak jarang bahasa Arab dianggap sebagai salah satu bahasa yang sulit dipelajari karena berbeda dengan bahasa Indonesia, baik dari segi huruf, susunan kalimat, dan segi lainnya. Hal tersebut menjadi tantangan tersendiri untuk para guru bahasa Arab dalam mengajarkannya di kelas.

Pada lembaga pendidikan tingkat Madrasah Tsanawiyah, salah satu faktor yang menjadikan bahasa Arab susah dipelajari adalah adanya sebagian siswa belum pernah belajar bahasa Arab sebelumnya, dengan kata lain pada tingkat sekolah dasar siswa belum pernah mempelajarinya sehigga menjadikan bahasa Arab asing untuk dipelajari. Dalam mempelajari bahasa asing yang dibutuhkan tidak hanya satu buku sebagai media pembelajaran, akan tetapi dibutuhkan buku penunjang atau buku pelengkap sebagai media pembelajaran pendukung. Seperti di sekolah Islam yang menggunakan kitab-kitab kuning maka dibutuhkan buku penjelasan (kitab syarah) sebagai pelengkap dan kamus untuk mengetahui arti kosa kata, kemudian pada tingkat MTs/MA dalam pembelajaran bahasa Arab menggunakan buku paket bahasa Arab, maka dibutuhkan LKS (lembar kerja siswa) sebagai pelengkap dan kamus untuk mengetahui artinya.

Buku paket atau buku cetak bahasa Arab adalah buku yang telah disusun berdasarkan kurikulum tertentu dan dijadikan acuan serta sumber utamapembelajaran bahasa Arab di kelas. Sedangkan kamus merupakan sebuah buku yang memuat kosakata pilihan yang umumnya disusun berdasarkan urutan alphabet dengan disertai penjelasan maknanya dan dilengkapi informasi lain yang berhubungan dengan kosakata, baik penjelasan tersebut menggunakan bahasa disajikan kata sama dengan kosakata yang ada maupun dengan bahasa lain. ${ }^{1}$ Kamus merupakan buku referensi atau rujukan yang berfungsi sebagai sumber informasi suatu kajian. ${ }^{2}$ Dari definisi tersebut kamus merupakan salah satu hal penting jika seseorang ingin memahami dan mempelajari suatu bahasa asing.

1. H.R. Taufiqurrahman, Leksikologi Bahasa Arab, (Malang: UIN Malang Pres, 2008), hlm.132.

2. Depdiknas, Kamus Besar Bahasa Indonesia, (Jakarta: Pusat Bahasa Depdiknas,2008), hlm.628. 
Bagi siswa tingkat MTs mencari arti kata dalam suatu kamus bukanlah suatu hal yang mudah, kamus bahasa Arab berbeda dengan kamus bahasa Indonesia, karena dalam kamus bahasa Arab jika ingin mencari arti suatu kata maka pada kamus umumnya harus menggunakan kata dasarnya, terkadang hal ini yang masih belum dipahami oleh siswa, maka dari itu dibutuhkan kamus yang sesuai dengan kebutuhan siswa agar mudah dalam pemakaiannya.

MTs Yapi (Yayasan Pembangunan Islam) Pakem Sleman Yogyakarta adalah sekolah berbasis agama Islam yang di dalamnya terdapat pelajaran-pelajaran agama, salah satunya adalah bahasa Arab. Berdasarkan observasi dan wawancara oleh siswa dan guru, penulis mengetahui bahwa bahan ajar yang digunakan adalah buku bahasa Arab siswa kurikulum 2013. MTs ini tidak menggunakan bahan ajar atau media tambahan yang lain seperti LKS (lembar kerja siswa) dan kamus.

Siswa di MTs Yapi Pakem Sleman Yogyakarta tidak diwajibkan untuk membawa kamus oleh guru, karena guru sendiri belum menemukan kamus yang cocok dan mudah digunakan sesuai dengan kebutuhan siswa. Siswa menyatakan bahwa jika mereka tidak mengetahui arti suatu kosa kata maka mereka bertanya langsung kepada guru. Hal tersebut mengakibatkan siswa tidak mandiri dan ketergantungan kepada guru. Berdasarkan wawancara dengan guru, guru membutuhkan kamus yang mudah digunakan oleh siswa agar siswa mudah dalam menggunakan kamus dalam pembelajaran bahasa Arab. Selain itu kamus yang disusun berdasarkan kebutuhan siswa yang mengacu pada buku siswa bahasa Arab MTs kurikulum 2013 belum ditemukan di pasaran.

Dari hasil penelusuran beberapa literature, peneliti menemukan beberapa karya ilmiah yang berhubungan dengan tema penelitian ini, diantaranya:

Pertama, skripsi yang ditulis oleh A Fahmi Nidhom Barlente dengan judul "Pengembangan Buku Ajar Fisika Berbasis Integrasi-Interkoneksi Model Konfirmatif pada Pokok Bahasan Gerak Lurus Kelas X SMA/MA". Persamaan dengan penelitian penulis adalah sama-sama mengembangkan sebuah prodok, perbedaannya terletak pada produk yang dikembangkan yaitu buku ajar pada mata pelajaran 
Fisika, sedangkan peneliti akan mengembangkan kamus bahasa Arab untuk siswa Madrasah Tsanawiyah kelas VIII. ${ }^{3}$

Kedua, skripsi yang ditulis oleh Nur Fitri Hidayanti dengan judul “Pengembangan Kamus Saku Arab-Indonesia Sebagai Penunjang Penggunaan Buku Al'Arabiyah Baina Yadaik Jilid II Di SMA IT Abu Bakar Yogyakarta". Penelitian tersebut membahas tentang pengembangan produk yaitu kamus untuk penunjang penggunaan buku Al-'Arabiyah Baina Yadaik dan yang dikembangkan adalah kamus saku, sedangkan produk yang akan dikembangkan dalam skripsi ini adalah kamus buku untuk penunjang penggunaan buku paket Madrasah Tsanawiyah kelas VIII. 4

Ketiga, jurnal yang ditulis oleh Saptiana dengan judul "Pengembangan Media Pembelajaran Kamus Tematik Tiga Bahasa (Indonesia, Arab, Inggris) untuk Menstimulasi Kognitif Anak Usia Dini". Hasil dari penelitian ini dapat disimpulkan bahwa produk kamus yang telah dikembangkan layak menjadi media pemebelajaran untuk menstimulasi kognitif anak usia dini. Kamus ini disusun berdasarkan pelajaran anak PAUD semester satu dan dua yang berjumlah delapan bab. Kamus ini lebih banyak menggunakan gambar untuk mendeskripsikan kosa katanya. Perbedaan dengan yang akan penulis teliti adalah penulis akan mengembangkan kamus berdasarkan buku paket MTs kelas delapan, kemudian penulis tidak menggunakan gambar dalam penyusunan kamus karena keterbatan kemampuan penulis. ${ }^{5}$

Buku siswa bahasa Arab MTs kurikulum 2013 terdiri dari tiga buku, yaitu buku untuk kelas VII, VIII, dan IX. Untuk buku kelas VIII dan kelas IX menggunakan full bahasa Arab, oleh karena itu sering kali siswa tidak mengetahui artinya. Dapat diketahui bahwa sulitnya siswa mengetahui arti dari sebuah kosa kata karena tidak adanya media bantu yang lain, dalam hal ini adalah kamus bahasa Arab.

\footnotetext{
3. A Fahmi Nidhom Barlente, "Pengembangan Buku Ajar Fisika Berbasis Integrasi-Interkoneksi Model Konfirmatif pada Pokok Bahasan Gerak Lurus Kelas X SMA/MA”, Skripsi Pendidikan Fisika, (Yogyakarta: Perpustakaan PPs. UIN Sunan kalijaga, 2014), t.d.

4. Nur Fitri Hidayanti, "Pengembangan Kamus Saku Arab-Indonesia Sebagai Penunjang Penggunaan Buku Al'Arabiyah Baina Yadaik Jilid II Di SMA IT Abu Bakar Yogyakarta", Skripsi Pendidikan Bahasa Arab, (Yogyakarta: Perpustakaan PPs. UIN Sunan kalijaga, 2015), t.d.

5. Saptiani, "Pengembangan Media Pembelajaran Kamus Tematik Tiga Bahasa (Indonesia, Arab, Inggris) untuk Menstimulasi Kognitif Anak Usia Dini”, Jurnal Pasca Sarjana PGRA, (Yogyakarta: UIN Sunan Kalijaga,2016), t.d.
} 
Berdasarkan beberapa permasalahan tersebut maka penulis merasa penting mengadakan penelitian pengembangan sebuah kamus yang disusun berdasarkan kebutuhan siswa yang mengacu pada buku siswa bahasa Arab MTs kurikulum 2013.

\section{METODE PENELITIAN}

Penelitian ini menggunakan pendekatan kualitatif dan kuantitatif dengan jenis penelitian dan pengembangan (reseach and development). Sumber data diambil dari beberapa wawancara diantaranya wawancara dengan guru bahasa Arab MTs Yapi Pakem Yogyakarta, siswa kelas 8 MTs Yapi Pakem Sleman Yogyakarta, ahli materi, dan ahli media. Jenis data yang digunakan dalam penelitian ini adalah (1) Data kualitatif yang berupa saran dan kritik dari dosen pembimbing, peer reviewer (penilaian teman sebaya) dan para penilai, yaitu ahli materi, ahli media, guru bahasa Arab. (2) Data kuantitatif, data ini akan digunakan untuk mengukur produk berdasarkan skor penilaian produk, yang akan memberikan penilaian adalah ahli materi, ahli media, dan guru bahasa Arab. Teknik pengumpulan data dengan cara observasi, wawancara, angket dan uji coba

Sugiyono mengemukakan 10 langkah dalam melakukan penelitian dan pengembangan (reseach and development) yaitu: Potensi dan masalah; pegumpulan data; desain produk, validasi desain, revisi desain; ujicobaproduk; revisi produk; ujicoba pemakaian; revisi produk; dan produksi massal6.

Namun dalam penelitian ini, peneliti menggunakanlangkah-langkah sebagai berikut:

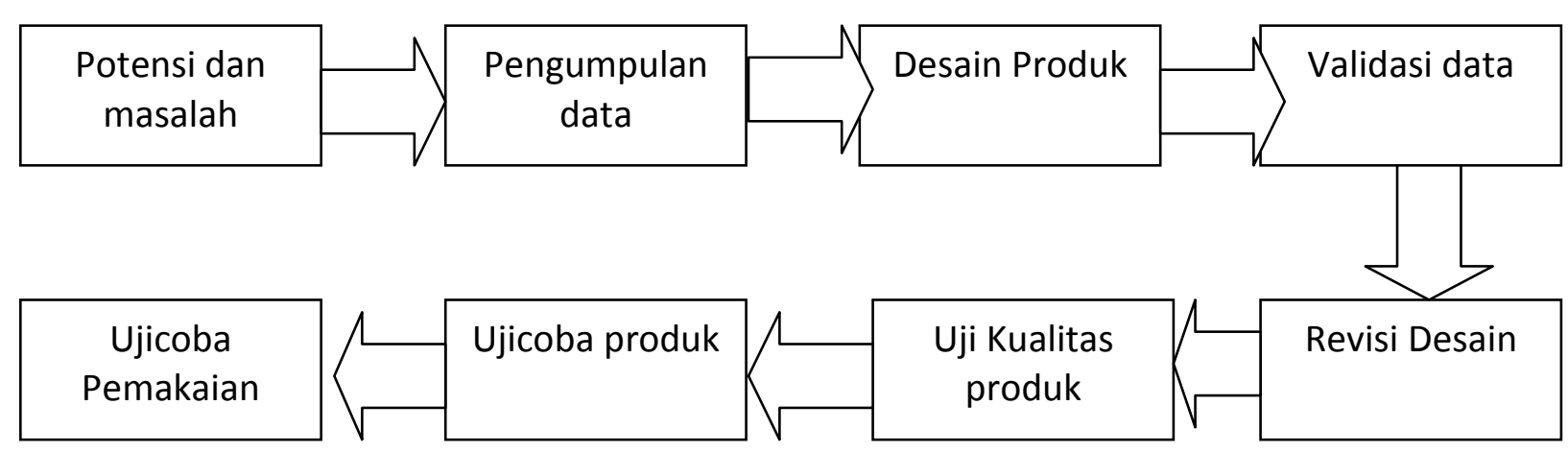

6. Sugiyono. Metode Penelitian Pendidikan: Pendekatan Kuantitatif, Kualitatif, dan R\&D. Bandung: Alfabeta, 2012, 409. 
Dari langkah-langkah tersebut, peneliti melihat potensi masalah di Madrasah Tsanawiyah Yapi (Yayasan Pembangunan Islam) Pakem Sleman Yogyakarta kelas VIII adalah terletak pada latar belakang siswa yang belum pernah belajar bahasa Arab sama sekali, sedangkan buku ajar yang digunakan adalah buku ajar yang berbahasa Arab secara keseluruhan. Dari permasalahan ini, peneliti menyimpulkan bahwa mereka membutuhkan sebuah buku penunjang untuk membantu proses belajar bahasa Arab, yaitu sebuah kamus yang akan mempermudah mereka dalam memahami buku ajar yang ada di sekolah. Proses pengumpulan data, dilakukan oleh peneliti dengan mengumpulkan dari berbagai data yang digunakan oleh kelas VIII Madrasah Tsanawiyah Yapi (Yayasan Pembangunan Islam), seperti kebutuhan tarkib yang digunakan di dalam kamus disesuaikan dengan buku ajar yang digunakan, atau kosakata yang dilengkapi dengan bentuk mufrad, mutsanna, dan jamak, dan lain sebagainya. Desain produk, yang direncanakan oleh peneliti adalah sebuah kamus yang digunakan dengan menggunakan aplikasi corel draw dan microsoft word untuk mempermudah peneliti dalam mendesain cover dan punggung buku, sedangkan isi dari kamus tersebut berpegang pada materi yang digunakan oleh kelas VIII Madrasah Tsanawiyah Yapi (Yayasan Pembangunan Islam) Pakem Sleman Yogyakarta. Revisi desain dilakukan oleh tiga orang peer reviewer dengan mengisi lembar saran dan kritik terhadap aspek desain, aspek isi kamus, dan aspek materi/tarkib terhadap produk yang dikembangkan. Uji kualitas produk dilakukan dengan meminta Penilaian kamus Arab-Indonesia untuk MTs kelas 8 dilakukan oleh ahli materi, ahli media, dan guru bahasa Arab MTs Yapi Pakem Sleman Yogyakarta. Ujicoba produk dilakukan pada enam siswa kelas VIII MTs Yapi Pakem Sleman dengan memberikan kamus Arab-Indonesia untuk MTs kelas 8, kemudian penulis menjelaskan tentang kamus tersebut dan cara menggunakannya. Ujicoba pemakaian dilakukan pada 22 siswa kelas VIII MTs Yapi Pakem Sleman. Pelaksanaan uji coba skala besar sama dengan uji coba skala kecil. 


\section{KAJIAN PUSTAKA}

\section{Definisi Kamus dan Macamnya}

Secara etimologi, kata kamus berasal dari kata bahasa Arab, yaitu Qaamus (bentuk jamaknya Qawaamus).7 Menurut C.L. Barnhart dalam buku karangan H.R. Taufiqurrahman, Definisi kamus adalah: "Sebuah buku yang memuat kosakata pilihan yang umumnya disusun berdasarkan urutan alphabet dengan disertai penjelasan maknanya dan dilengkapi informasi lain yang berhubungan dengan kosakata, baik penjelasan tersebut menggunakan bahasa disajikan kata sama dengan kosakata yang ada maupun dengan bahasa lain". ${ }^{8}$

Terdapat beberapa jenis kamus diantaranya, yaitu :

Kamus Bahasa (lughawi).

Kamus bahasa hanya memuat satu bahasa, sehingga biasanya, pemaknaan kata hanya menyebut sinonim atau definisi kata tersebut. Misalnya, kamus AlMunjid (Arab-Arab), kamus Mukhtar Ash-Shihah (Arab-Arab), Kamus Lengkap Inggris-Inggris, dan lain sebagainnya.

Kamus Terjemah.

Kamus terjemah memuat kata-kata asing yang kemudian dijelaskan satu persatu dengan mencari padanan makna yang disesuaikan dengan bahasa nasional atau bahasa pemakai kamus. Dalam penyusunan kamus terjemah dibutuhkan skill penyusun yang mumpuni di bidang ilmu terjemah. Selain itu penyusun kamus dituntut untuk menguasai dua bahasa (bilingual) secara baik.

Kamus Buku (mu'jam al-kitab)

Kamus yang dibuat khusus untuk memahami makna dari kosakata yang termuat dalam sebuah buku. Misalnya buku berjudul Al-'Arabiyah Baina Yadaika yang diterbitkan Muassasah Al-Waqf Al-Islamy Al-'Arabiyah Lil Jami' itu, juga dilengkapi dengan sebuah buku kamus khusus berjudul Mu'jam Al-'Arabiyah Baina Yadaika. Kamus semacam ini disebut Mu'jam Al-Kitab, sebuah kamus yang berfungsi untuk memahami semua kosakata yang termuat di dalam buku ajar dan hanya terbatas pada materi buku ajar.

7. Munawwir, Kamus Al-Munawwir Arab-Indonesia Lengkap, (Surabaya: Pustaka Progressif, 1997), hlm.1156.

8. H.R.Taufiqurrahman, Leksikologi..., hlm.132.

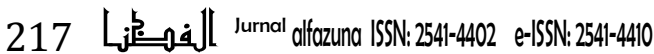


Kamus Tematik (Maudhu'i)

Disebut juga kamus maknawi, karena kata-kata yang terhimpun di dalam kamus disusun secara tematik berdasarkan topik-topik tertentu yang memiliki makna sebidang. Misalnya, untuk tema lawn (warna) dimasukkan kata ahmar (merah), azraq (biru), abyadh (putih), dan seterusnya. Untuk kamus tematik, penyusun mengklasifikasikan kata-kata yang memiliki makna serumpun ke dalam tema-tema tertentu. Kamus tematik bahasa Arab versi kuno, antara lain: Kamus AlMukhassash karya Ali bin Ismail (1007-1066 M) dari Andalus yang lebih dikenal dengan nama Ibnu Sidah.

Kamus Devariatif (Isytiqaqi)

Disebut juga dengan istilah Kamus Etimologis, yaitu sebuah kamus yang membahas asal-usul sebuah kata, sehingga kamus devariatif/etimologis berfungsi untuk menginformasikan asal usul lafal/kosakata. Apakah sebuah lafal/kata berasal dari bahasa Arab, Persi,Yunani, atau lainnya.

Kamus Evolutif (Tathawwuri)

Kamus yang lebih memprioritaskan sejarah perkembangan makna dari sebuah kata, bukan lafalnya. Kamus evolutif memberikan informasi tentang perluasan makna, perubahannya, sebab-sebab perubahan makna dan sebagainya. Misalnya, perkembangan kata adab atau sufi sejak masa jahiliyah hingga masa kini. Untuk mencarinya kini telah terafiliasi dalam ensiklopedi atau bahkan buku-buku sejarah.

Kamus Digital

Yaitu, perangkat lunak komputer (software) yang memuat program terjemah atau kamus bahasa yang bisa dijalankan melalui media eketronik seperti komputer, handphone, PDA, dan perangkat lainnya. Contohnya: Al-Mawarid AlQuareeb, kamus Mufid 1.0, kamus Golden Al-Wafi Arabic Translator.

Kamus Spesialis (Takhashshushi)

Yaitu kamus yang hanya menghimpun kata-kata yang ada dalam satu bidang/disiplin ilmu tertentu. Ada kamus kedokteran, kamus pertanian, kamus musik, dan lainnya. Contohnya adalah kamus At-Tadzkirah yang ditulis oleh Dawud Al-Anthaqi al-Dharir. Kamus ini memuat kata-kata yang khusus berhubungan dengan serangga.

Kamus Online 
Yaitu program kamus secara yang bisa diakses melalui internet. Para netter sering memanfaatkan jasa terjemahan kamus online pada saat browsing ke situssitus di internet. Salah satu kamus online yang populer adalah Google Translate yang menyediakan jasa penerjemahan lebih dari 20 bahasa asing, termasuk bahasa Arab. $^{9}$

Kamus yang dikembangkan dalam penelitian ini termasuk jenis kamus buku (mu'jam al-kitab) karena berfungsi untuk memahami kosakata yang termuat di dalam buku ajar dan hanya terbatas pada materi buku ajar tersebut, selain itu kamus yang dikembangkan termasuk ke dalam kategori kamus terjemah karena menyajikan dua bahasa, yaitu bahasa Arab dan bahasa Indonesia.

\section{Komponen Kamus}

Kamus yang baik dan dinilai cukup lengkap dapat dievaluasi atau dilihat dari keberadaan komponen baku yang menjadi ukuran standar sebuah kamus. Untuk melihat kelengkapan kompnen sebuah kamus, Dr. Ali Al-Qasimy menawarkan beberapa poin yang perlu diperhatikan. Jika semua poin tersebut terpenuhi sebuah kamus, maka kamus tersebut dapat dikategorikan sebagai kamus yang lengkap. Isi kamus yang lengkap memuat tiga bagian, yaitu:

Bagian Awal

Adapun bagian awal dari kamus terdiri dari: tujuan penyusunan kamus, sumber yang digunakan, latar belakang penyusunan kamus, petunjuk penggunaan kamus, pedoman tata bahasa, jumlah materi/kata dalam kamus, keterangan singkatan, makna simbol atau gambar, kaidah transliterasi, dan informasi lainnya. Bagian Utama

Bagian utama pada kamus terdiri dari: font (khat) yang digunakan, model kolom, informasi fonetik (ashwat), informasi morfologi (sharaf), informasi sintaksis (nahwu), informasi semantic (dalalah), contoh pemakaian kata, dalil atau syawahid (bukti pemaknaan), gambar-gambar, informasi derivasi kata.

Bagian Akhir

Adapun bagian akhir dari kamus terdiri dari: lampiran, table, peta, kronologi sejarah, rumus-rumus, tenatng penyusunan, dan sebagainya. Selain aspek isi, penilaian terhadap kamus juga mencakup aspek penampilan atau performance

\section{Ibid. hlm.153.}


(syakl). Apakah kamus tersebut dicetak dengan kualitas baik, memiliki desain cover yang artistik, harganya terjangkau, selalu muncul edisi revisi untuk mengikuti perkembangan bahasa, dan hal-hal lain yang menjadi pertimbangan dalam mengukur tingkat kelengkapan sebuah kamus. ${ }^{10}$

\section{Kriteria Kamus}

Beberapa kriteria kamus menurut Menurut Syihabuddin, diantaranya yaitu: Pertama: Kelengkapan, terdapat beberapa kriteria kelengkapan kamus yang ideal mencakup beberapa hal, yaitu: (a) Terdapat simbol sederhana yang menerangkan cara pelafalan kata yang dijadikan lema atau entri, (b) Pemakaian definisi yang baik dan mudah, (c) penyajian kata yang mudah kemudian diikuti dengan kata bentukan lainnya, (d) penyajian ungkapan dan istilah yang frekuensi pemakaiannya sangat tinggi, (e) penyajian informasi kebudayaan dan peradaban, dan (f) penyajian kata pengantar berkenaan dengan dengan khalayak sasaran kamus, cara pemakaian kamus dan kaidah bahasa paling pokok; Kedua: Keringkasan, kamus yang baik, salah satu karakteristiknya adalah yang memfokuskan pembahasan dan uraiannya kepada hal-hal yang subtansial; ketiga Kecermatan, kecermatan berkaitan erat dengan masalah objektifitas uraian di dalam kamus. Untuk meraih objektifitas, biasanya kamus yang baik dilengkapi dengan foto, gambar, ilustrasi, dan contoh; keempat Kemudahan Penjelasan, kamus yang baik hendaknya menyajikan informasi yang berkaitan erat dengan topik yang disajikan sebagai lema. Di samping itu, informasi hendaknya disuguhkan secara sederhana sehingga pembaca dapat menangkap makna dengan mudah. Untuk memudahkan pemahaman, biasanya digunakan sarana penjelas seperti tanda panah, pemberian warna yang menonjol pada bagian yang penting, penempatan gambar secara proporsional, dan pemakaian nomor. ${ }^{11}$

\section{HASIL PENELITIAN DAN PEMBAHASAN \\ Desain produk}

Berdasarkan informasi yang penulis dapatkan diatas. Penulis mulai menyusun kamus bahasa Arab untuk madrasah kelas VIII dengan aplikasi corel 
draw dan microsoft word. Berikut ini adalah gambar cover, punggung buku, dan isi kamus pada awal penyusunan kamus. Pembuatan cover dan punggung buku menggunakan aplikasi corel draw.

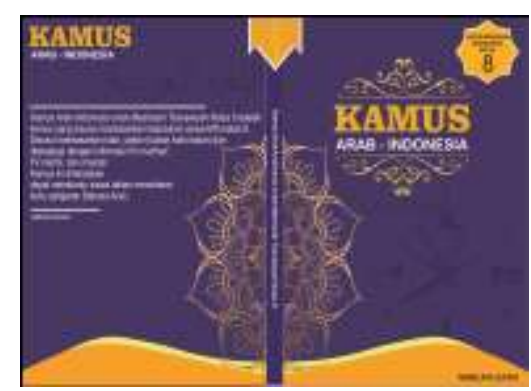

\section{Gambar 1.1 Desain Cover dan Punggung Buku Awal}

Penyusunan tarkib disesuaikan dengan materi tarkib yang dipelajari oleh siswa kelas VIII. Tujuannya untuk membantu siswa memahami tarkib tersebut.

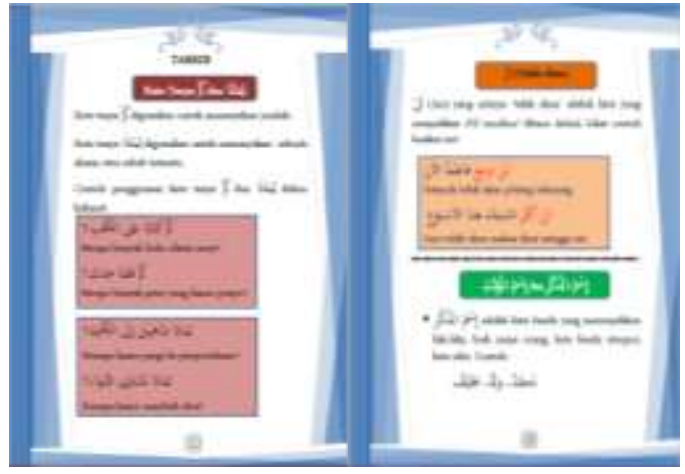

Gambar 1.2 Salah Satu Tampilan Halaman Tarkib

Kosakata yang dijadikan lema di dalam kamus ini disusun secara alfabetis yakni dari huruf alif sampai $y a^{\prime}$. Selain itu kosakata berbentuk kata benda dilengkapi dengan kata tunggal dan pluralnya, kosakata berbentuk kata kerja dilengkapi dengan fi'il mudhari, fi'il madhi, dan masdar.

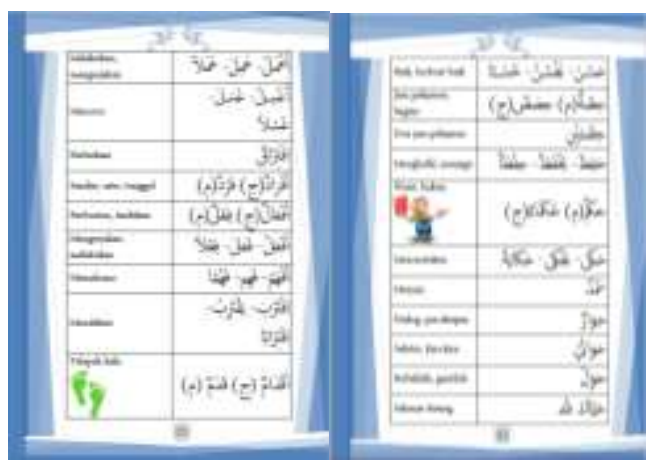

Gambar 1.3 tampilan isi kamus awal

Kamus ini terdiri dari daftar isi, petunjuk penggunaan kamus, tarkib, lema, dan daftar pustaka. 


\section{Validasi dan Revisi Desain}

Validasi bertujuan untuk mengetahui kebenaran produk dan kualitas produk yang dikembangkan agar mendapat kritik, saran, dan masukan untuk perbaikan produk pada tahap selanjutnya. Validasi dilakukan oleh tiga orang peer reviewer dengan mengisi lembar saran dan kritik terhadap aspek desain, aspek isi kamus, dan aspek materi/tarkib terhadap produk yang dikembangkan. Lembar saran dan kritik tersebut kemudian menjadi acuan dalam revisi produk agar menjadi lebih baik. Masukan dan kritik dari peer reviewer disajikan dalam bentuk tabel sebagai berikut:

\begin{tabular}{|c|c|}
\hline $\begin{array}{c}\text { Peer } \\
\text { Reviewer }\end{array}$ & Saran dan Kritik \\
\hline 1 & $\begin{array}{l}\text { Aspek Desain } \\
\text { Dari aspek desain sudah bagus, cover menarik berbeda dengan kamus lain } \\
\text { biasanya cover penuh dengan tulisan. Tapi kamus karya Nabilah Ulfah ini } \\
\text { menarik dan minimalis. } \\
\text { Aspek isi kamus } \\
\text { - Isi kamus pas, tidak terlalu tebal dan tidak terlalu tipis. Jadi, saat orang } \\
\text { - } \text { melihat kamus tersebut penasaran } \\
\text { - } \quad \text { Dalam kamus ada gambar dan itu menarik perhatian siswa, namun } \\
\text { akan lebih baik jika gambar tersebut di desain pada awal judul huruf } \\
\text { hijaiyah } \\
\text { Dalam kamus tersebut terdapat kertas atau tulisan yang warna warni } \\
\text { dan itu sangat menarik } \\
\text { Aspek materi/tarkib } \\
\text { Bagus secara keseluruhan materi }\end{array}$ \\
\hline 2 & $\begin{array}{l}\text { Aspek desain } \\
\text { - } \quad \text { Coba desain kamusnya dari kanan ke kiri } \\
\text { - Tambah gambar yang menarik } \\
\text { - Perbanyak gambar dan tambah motivasi } \\
\text { Aspek isi } \\
\text { - Awal huruf harus sama/ setara diatas } \\
\text { Awal huruf bisa dibikin timbul disamping kamus } \\
\text { Aspek materi/tarkib } \\
\text { - Kurang gambar agak membosankan } \\
\text { - Tudah bagus }\end{array}$ \\
\hline 3 & $\begin{array}{l}\text { Aspek desain } \\
\text { - Desain sudah bagus dan menarik motifnya. Sebaiknya warnanya pakai } \\
\text { warna yang terang }\end{array}$ \\
\hline
\end{tabular}




\begin{tabular}{|l|l|}
\hline & $\begin{array}{l}\text { Aspek desain disesuaikan dengan sasaran } \\
\text { Aspek isi kamus } \\
\bullet \quad \text { Alangkah baiknya dilengkapi dengan gambar ilustrasi } \\
\bullet \quad \text { Aspek isi kamus kurang padat }\end{array}$ \\
$\begin{array}{l}\text { Aspek materi } \\
\text { - Secara keseluruhan sudah bagus dan sesuai, qowaid lebih baik di } \\
\text { sesuaikan dengan aturan yang berlaku dan konsultasi dengan ahli } \\
\text { materi }\end{array}$ \\
\hline
\end{tabular}

Tabel 1.1 saran dan kritik peer reviewer

Dari saran dan kritik peer reviewer, ada beberapa saran yang tidak dilakukan oleh peneliti karena beberapa alasan, antara lain:

1. Desain kamus dari kanan ke kiri. Penulis tidak melakukan saran ini karena karena penulis mengikuti desain buku paket yang dijadikan acuan yaitu dari kiri ke kanan.

2. Awal huruf bisa dibikin timbul disamping kamus. Penulis tidak melakukan saran ini karena kamus tidak terlalu tebal sehingga huruf hijaiyah di samping lembaran kurang perlu.

\section{UJi Kualitas dan Revisi Produk}

Penilaian kamus Arab-Indonesia untuk MTs kelas 8 dilakukan oleh ahli materi, ahli media, dan guru bahasa Arab MTs Yapi Pakem Sleman Yogyakarta. Tujuan dari penilaian ini untuk mengetahui kualitas kamus yang dikembangkan berdasarkan prespektif ahli materi, ahli media dan guru bahasa Arab. Data yang diperoleh dari penilaian merupakan data kuantitatif dan data kualitatif, data kuantitatif berupa angket penilaian sedangkan data kualitatif berupa saran dan masukan dari ahli yang akan digunakan sebagai pedoman dalam revisi produk.

1. Penilaian ahli materi

Aspek yang dinilai oleh ahli materi/bahasa yaitu kelayakan isi dan kebahasaan. Data hasil penilaian oleh ahli materi disajikan dalam tabel berikut: 


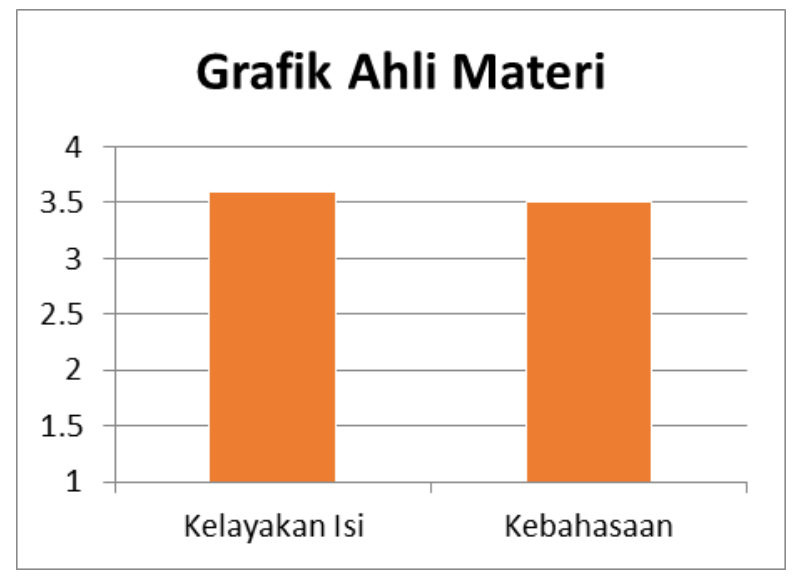

\section{Gambar 1.4 Grafik Presentase Hasil Penilaian Ahli Materi}

Selain memberikan penilaian, ahli materi juga memberikan saran dan masukan terhadap produk, saran dan masukan dari ahli materi sebagai berikut:

- Kata kerja bahasa Arab harus sesuai dengan subyeknya baik itu kata kerja lampau/pun yang sekarang. Sebagian kata kerja lampau banyak tidak tepat subyeknya dengan kk sekarang. (tolong direvisi)

- Makna kata kerja dalam bahasa Arab pasti mengandung subjek. Di kamus ini maknya kata kerja belum disebutkan subyeknya.

2. Penilaian ahli media

Ahli media akan menilai dari aspek kelayakan isi, aspek kebahasaan dan aspek layout dan grafis. Data dari hasil penilaian ahli media akan dipaparkan pada tabel berikut:

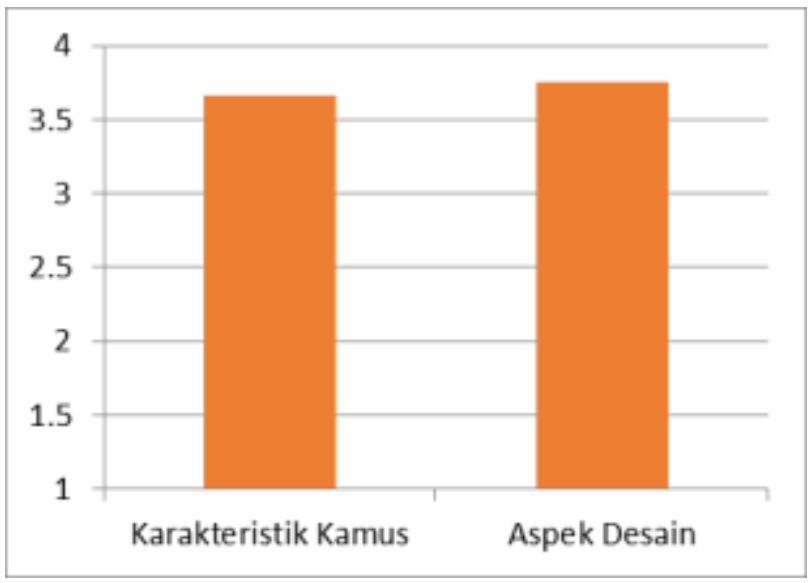

Gambar 1.5 Grafik Presentase Hasil Penilaian Ahli Media 
Selain memberikan penilaian, ahli media juga memberikan saran dan masukan terhadap produk, saran dan masukan dari ahli media sebagai berikut:

- Peletakan nama di cover disesuaikan lagi

- Perlu penyesuaian mufrodat dengan materi yang ada untuk Tsanawiyah kelas 8

Setelah melakukan tahap validasi oleh para peer reviewer dan tahap uji kualitas kamus oleh para ahli, peneliti melakukan perbaikan berdasarkan saran dan masukan yang telah diberikan. Berikut gambar sebelum dan sesudah perbaikan/revisi.
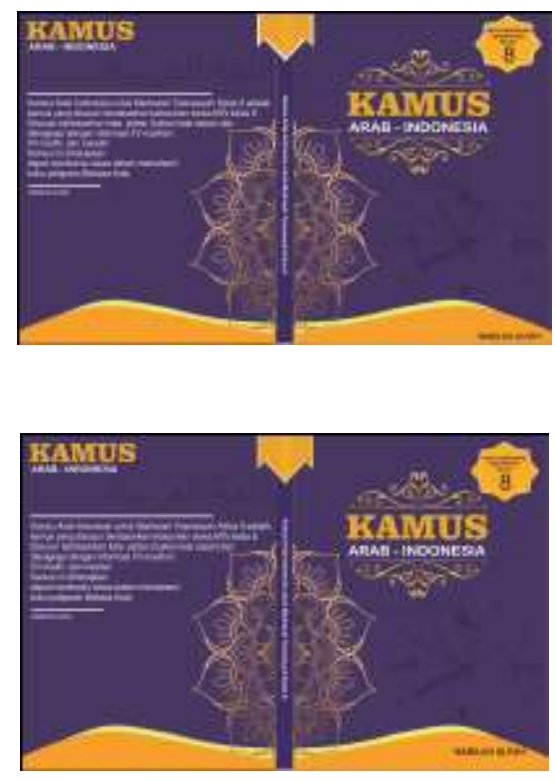

Gambar 7. Tampilan Cover Dan Punggung Kamus Sebelum dan Sesudah Revisi

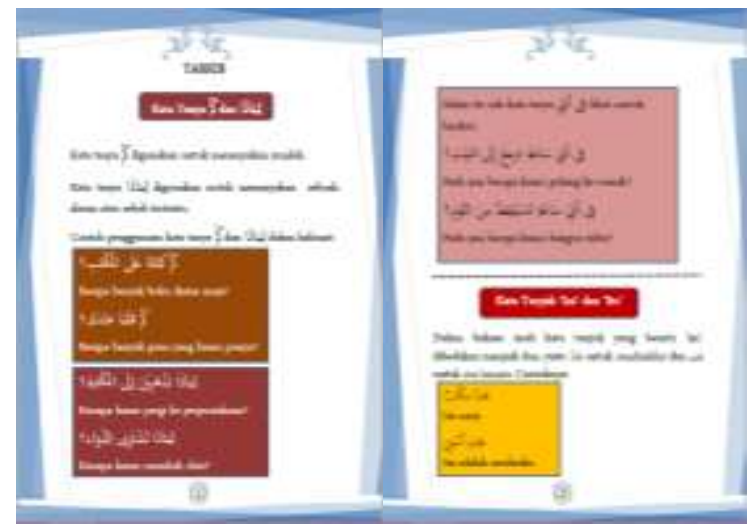

Gambar 1.7 Tampilan Halaman Kamus Sebelum dan Sesudah Revisi 


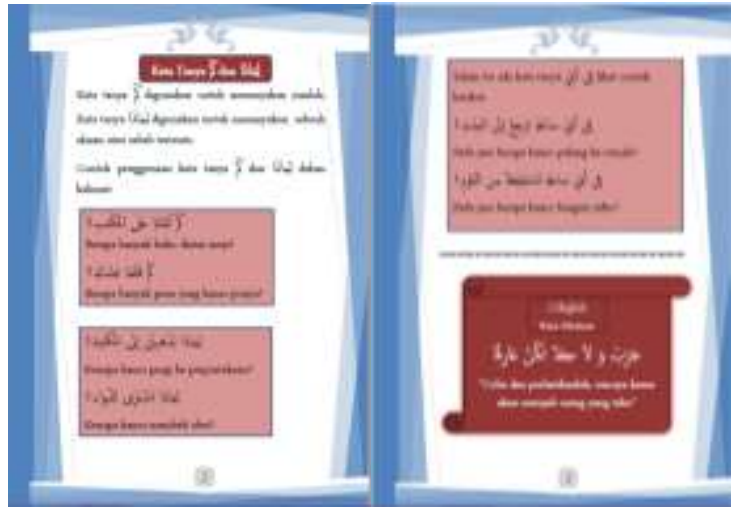

\section{Gambar 1.8 Tampilan Halaman Kamus Sebelum dan Sesudah Revisi}

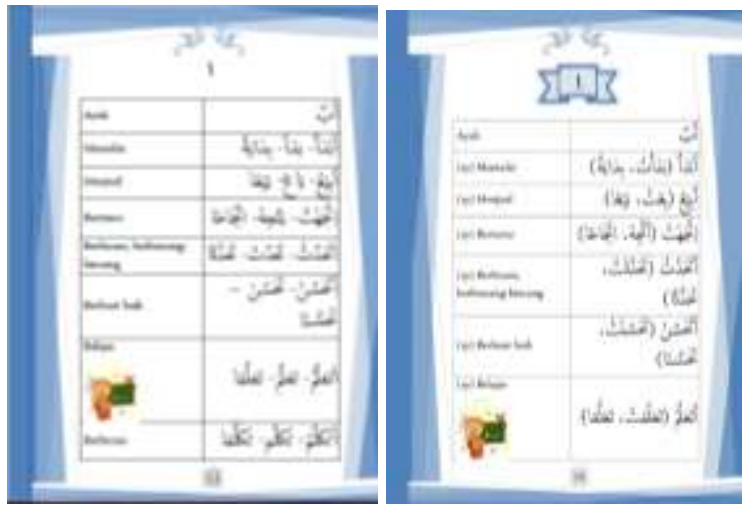

Jenis huruf yang digunakan sebelum dan sesudah revisi adalah Arabic Typesetting. Beberapa perbaikan yang penulis lakukan antara lain: penambahan subjek pada kosa kata yang berbentuk kata kerja. Subjek dalam kamus ini yaitu 'saya' disingkat menjadi 'sy', 'kamu' disingkat menjadi 'km', 'laki-laki' disingkat menjadi 'lk', 'perempuan' disingkat menjadi 'pr', kami, mereka, dan dia. Selain itu ukuran font Arab yang awalnya 48 diubah menjadi 44.

Penulis melakukan penambahan beberapa gambar pada beberapa kosa kata. Selain itu penulis melakukan perbaikan pada susunan kata kerja dan penyesuaian subjek, untuk lebih jelas penulis paparkan sebagai berikut.

$$
\begin{aligned}
& \text { أَبْدَأُ- بَدَأَ- بِدَايَةً (sebelum revisi) }
\end{aligned}
$$

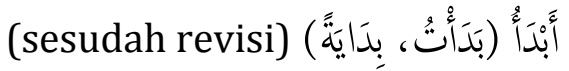

Penulis menggunakan microsoft word untuk menyusun layout kamus dan untuk mengurutkan kosa kata dari huruf alif sampai $y a^{\prime}$. Untuk cover dan punggung kamus menggunakan corel draw. 


\section{Uji Coba Produk}

Uji coba produk merupakan uji coba skala kecil yang dilakukan pada enam siswa kelas VIII MTs Yapi Pakem Sleman dengan memberikan kamus ArabIndonesia untuk MTs kelas 8, kemudian penulis menjelaskan tentang kamus tersebut dan cara menggunakannya. Selanjutnya para siswa diminta untuk menerjemahkan materi yang diberikan. Setelah selesai siswa diberikan angket yang berisi penilaian respon siswa terhadap kamus, tujuan uji coba produk untuk mengetahui gambaran awal tanggapan peserta didik terhadap produk yang dikembangkan.

Aspek-aspek yang dinilai oleh para siswa antara lain aspek kelayakan isi, penyajian, kebahasaan. Berdasarkan hasil perhitungan skor rata-rata keseluruhan, respon peserta didik terhadap kamus Arab-Indonesia untuk MTs kelas 8 memperoleh respon setuju dengan skor rata-rata 3,25. Hal ini menyatakan bahwa menurut siswa kamus Arab-Indonesia untuk MTs kelas 8 dapat membantu siswa dalam memahami mufrodat dan materi yang terdapat pada buku paket MTs kelas 8.

\section{Uji Coba Pemakaian}

Uji coba pemakaian merupakan uji coba skala besar yang dilakukan pada 22 siswa kelas VIII MTs Yapi Pakem Sleman. Pelaksanaan uji coba skala besar sama dengan uji coba skala kecil, yakni memberikan kamus Arab-Indonesia untuk MTs kelas 8 kamudian para siswa menerjemahkan materi yang diberikan. Setelah selesai siswa diberi angket berupa item-item penilaian terhadap kamus.

Aspek-aspek yang dinilai oleh para siswa antara lain aspek kelayakan isi, penyajian, kebahasaan. Berdasarkan hasil perhitungan skor rata-rata keseluruhan, respon peserta didik terhadap kamus Arab-Indonesia untuk MTs kelas 8 memperoleh respon sangat setuju dengan skor rata-rata 3,66.

Pada ujicoba skala kecil dan skala besar terdapat perbedaan skor rata-rata pada tiap aspek maupun keseluruhan. Hal ini dipengaruhi oleh perbedaan pada jumlah responden, semakin besar jumlah respoden maka semakin besar skor ratarata yang diperoleh begitupun sebaliknya. Berikut ini penulis sajikan 
perbandingan skor rata-rata uji coba skala kecil dan skala besar dalam bentuk grafik.

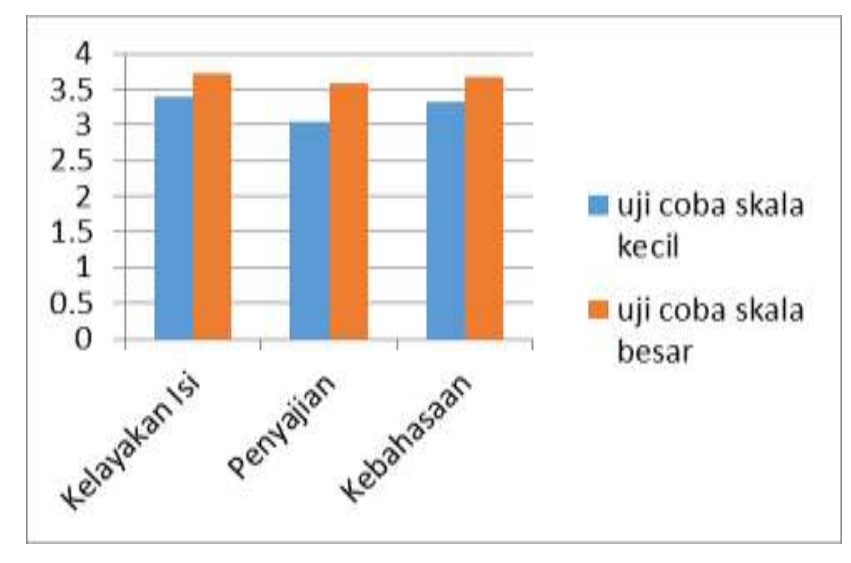

Gambar 1. 9. Grafik Perbandingan Skor Rata-Rata Antara Uji Coba Skala Kecil dan Skala Besar

Pada grafik perbandingan dapat dilihat bahwa pada uji boba skala besar terdapat kenaikan pada setiap aspeknya. Kenaikan skor rata-rata ini menunjukkan bahwa kamus Arab-Indonesia untuk MTs kelas VIII ini mendapat respon positif dari siswa.

\section{Respon Guru}

Aspek yang dinilai oleh guru bahasa Arab adalah aspek kelayakan isi, fungsi dan manfaat, dan aspek layout dan grafis. Penilaian oleh guru bahasa Arab dilakukan oleh dua guru, hasil penilaian guru bahasa Arab dapat dilihat pada tabel berikut ini.

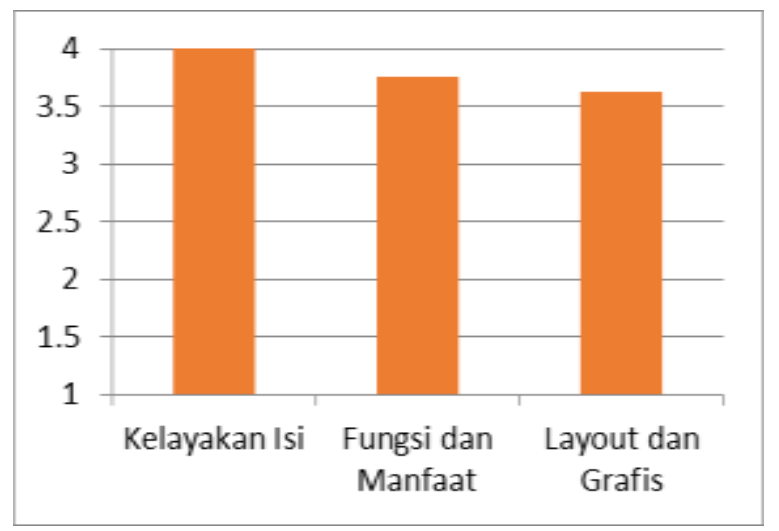

Gambar 1.10. Grafik Presentase Hasil Penilaian Guru Bahasa Arab Kajian Produk Akhir 
Kajian produk akhir yaitu pembuatan produk masal. Tahap ini merupakan tahap akhir setelah melalui beberapa uji coba dan revisi untuk menghasilkan produk yang efektif, namun karena proses pengembangan kamus ini hanya sampai pada uji kualitas produk dan respon guru dan siswa terhadap produk kamus ArabIndonesia untuk MTs kelas 8, oleh karena itu tahap kajian produk akhir ini tidak dilakukan.

\section{KESIMPULAN}

Adapun kesimpulan dari penelitian ini adalah penelitian ini telah berhasil mengembangkan media pembelajaran berupa kamus Arab-Indonesia untuk MTs kelas 8, yang dijadikan sebagai penunjang penggunaan buku ajar/ buku paket MTs kelas 8. Adapun hasil penilaian dari ahli bahasa mendapatkan skor rata-rata 3,55 dari skor tertinggi 4,00 dengan kriteria Sangat Baik (SB). Hasil penilaian dari ahli media mendapatkan skor rata-rata 3,71 dengan kriteria Sangat Baik (SB). Dari hasil penilaian para ahli tersebut, kamus Arab-Indonesia untuk MTs kelas 8 memiliki kualitas kamus Sangat Baik (SB).

Pada uji coba produk atau uji coba skala kecil menghasilkan respon peserta didik terhadap kamus Arab-Indonesia untuk MTs kelas 8 yaitu Setuju (S) dengan skor rata-rata 3,25. Sedangkan pada uji coba pemakaian atau uji coba skala besar menghasilkan respon peserta didik terhadap kamus Arab-Indonesia untuk MTs kelas 8 yaitu Sangat Setuju (SS) dengan skor rata-rata 3,66. Selain itu respon guru bahasa Arab terhadap kamus ini adalah Sangat Setuju (SS) dengan skor rata-rata 3,79 . 


\section{DAFTAR PUSTAKA}

Barlente, A Fahmi Nidhom. Pengembangan Buku Ajar Fisika Berbasis IntegrasiInterkoneksi Model Konfirmatif pada Pokok Bahasan Gerak Lurus Kelas X SMA/MA, Skripsi Pendidikan Fisika, Yogyakarta: Perpustakaan PPs. UIN Sunan kalijaga, 2014.

Depdiknas, Kamus Besar Bahasa Indonesia, Jakarta: Pusat Bahasa Depdiknas, 2008.

Hidayanti, Nur Fitri. Pengembangan Kamus Saku Arab-Indonesia Sebagai Penunjang Penggunaan Buku Al'Arabiyah Baina Yadaik Jilid II Di SMA IT Abu Bakar Yogyakarta, Skripsi Pendidikan Bahasa Arab, Yogyakarta: Perpustakaan PPs. UIN Sunan kalijaga, 2015.

Munawwir, Kamus Al-Munawwir Arab-Indonesia Lengkap, Surabaya: Pustaka Progressif, 1997.

Prastowo, Andi. Pengembangan Bahan Ajar Tematik, Tinjauan Teori dan Praktik, Jakarta: Kencana Prenadamedia Group, 2014.

Saptiani, Pengembangan Media Pembelajaran Kamus Tematik Tiga Bahasa (Indonesia, Arab, Inggris) untuk Menstimulasi Kognitif Anak Usia Dini", Jurnal Pasca Sarjana PGRA, Yogyakarta: UIN Sunan Kalijaga, 2016.

Sugiyono. Metode Penelitian Pendidikan: Pendekatan Kuantitatif, Kualitatif, dan R\&D.Bandung: Alfabeta, 2012.

Taufiqurrahman, H.R. Leksikologi Bahasa Arab, Malang: UIN Malang Pres, 2008.

Tim Penyusun, Buku Siswa Bahasa Arab Pendekatan Saintifik Kurukulum 2013, Jakarta: Kemenag RI, 2015. 